\title{
Species composition and diversity of phytoplankton in some crenic habitats of district Anantnag, Kashmir
}

\author{
Showkat Ahmad Lone, Ashok K. Pandit and Sami Ullah Bhat \\ Department of Environmental Science, University of Kashmir, Srinagar, India
}

\begin{abstract}
Seven crenic habitats from district Anantnag were evaluated for composition and diversity of phytoplankton over a period of one year extended from September 2010 to August 2011. A total of 67 species were recorded during the entire study which belonged to four classes of algae namely Chlorophyceae, Bacillariophyceae, Cyanophyceae and Euglenophyceae. Class Bacillariophyceae was found to be dominant throughout the study period. Utmost diverse genera encountered in the present study belonged to Nitzischia, Synedra and Oscillatoria. Amongst the reported taxa, Binucleara tatarana, Hormidium subtile, Cerotonis arcus, Diatomella balfouriana. Gommphonema gracile, Navicula sp. and Microspora amoena were found almost throughout the study period. Further, springs showed greater species richness, composition in summer and autumn seasons.
\end{abstract}

Keywords: Phytoplankton, Crenic habitats, Springs, Species diversity, Chlorophyceae, Bacillariophyceae, Cyanophyceae, Euglenophyceae.

\section{INTRODUCTION}

Springs result from water table intersection with the earth's surface, or groundwater rise under hydrostatic pressure to the surface through rock faults, fractures or depressions (Death et al. 2004). They are widely distributed over the landscape, but vary greatly in morphology and size, ranging from minor seepages from bedrock faces, to alluvial springs in braided river landscapes, to resurgences in karst upto very large vents discharging many thousands of litres per second. Springs represent a triangular interaction between groundwater, surface water, and terrestrial ecosystems.

Springs are also represented with distinctive flora and fauna, with high levels of local endemism (Knott and Jasinska 1998). Phytoplankton succession is a wellinvestigated phenomenon in aquatic ecology and several studies have described the patterns and underlying mechanisms of the seasonal dynamics (Rothhaupt, 2000). However, the knowledge of the composition and abundance of phytoplanktonic organisms constitutes an indispensable feature for the assessment of the trophic status in springs and for the evaluation of the possible or optimal utilization of different water resources. Phytoplankton form the basis of the food chain in openwater resources and acts as an indicator of the water quality. Some phytoplankton species especially belonging to cyanophyceae are known to be harmful to humans on account of their capability to release toxic substances. Up-to-date there have been only occasional studies of the springs in Kashmir and little is known about their limnological aspects and possible, appropriate, management strategies (Soylu et al., 2007). Thus, the present study was aimed at evaluating the seasonal variation in the diversity and composition of the phytoplankton to cover the existing gap in the knowledge about the phytoplanktonic assemblages in these crenic habitats of Kashmir valley. 


\section{Study area and study sites}

Kashmir valley is one of the most beautiful and gratifying state so is called Switzerland of Asia.God has bestowed this valley with all the charm and scenery by which it is also called paradise on earth. Kashmir is one of the three administrative divisions in Jammu and Kashmir state and consists of Anantnag, Baramulla, Budgam, Bandipore, Ganderbal, Kupwara, Kulgam, Pulwama, Shopian and Srinagar districts. The study was carried out in Anantnag district as it possesses limitless springs which is reflected from its name viz, 'anant' meaning limitless and 'nag' meaning springs.

Seven springs in three tehsils of district Anantnag were choosen for carrying out the study viz., Himalinag and Malakhnag in Anantnag tehsil; Kirkadalnag and Parinag in Bijbehara tehsil; Dubnagin, Naranag, and Batnagin in Pahalgam tehsil. The coordinates of the study site and map is given in Table1 and Fig.1.

Table 1: Description of selected sites of district Anantnag

\begin{tabular}{|l|l|l|l|l|}
\hline Sites & Latitude (N) & Longitude (E) & Location & Bottom substrate \\
\hline Himalinag & $33^{0} 44^{\prime} 01.6^{\prime \prime}$ & $75^{0} 09^{\prime} 42.4^{\prime \prime}$ & Anantnag tehsil & Boulders \\
\hline Malakhnag & $33^{0} 43^{\prime} 44.6^{\prime \prime}$ & $75^{0} 09^{\prime} 15.6^{\prime \prime}$ & Anantnag tehsil & Boulders \&sand \\
\hline Kirkadalnag & $33^{0} 47^{\prime} 52.6^{\prime \prime}$ & $75^{0} 07^{\prime} 09.7^{\prime \prime}$ & Bijbehara tehsil & Flattened stones \\
\hline Parinag & $33^{0} 47^{\prime} 34.8^{\prime \prime}$ & $75^{0} 08^{\prime} 19.8^{\prime \prime}$ & Bijbehara tehsil & Muddy \\
\hline Dubnagin & $33^{0} 52^{\prime} 54.3^{\prime \prime}$ & $75^{0} 14^{\prime} 59.6^{\prime \prime}$ & Pahalgam tehsil & Mud \& sand \\
\hline Naranag & $33^{0} 51^{\prime} 10.2^{\prime \prime}$ & $75^{0} 14^{\prime} 15.8^{\prime \prime}$ & Pahalgam tehsil & Muddy \\
\hline Batnagin & $33^{0} 51^{\prime} 11.2^{\prime \prime}$ & $75^{0} 14^{\prime} 15.3^{\prime \prime}$ & Pahalgam tehsil & Small boulders \\
\hline
\end{tabular}

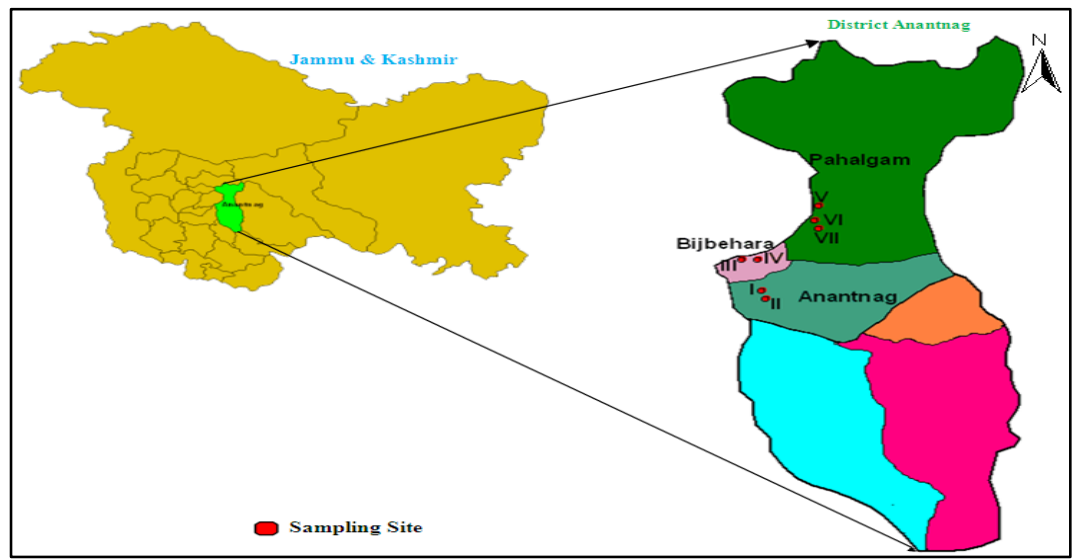

Fig.1: Map showing location of seven springs in District Anantnag of Kashmir in J\&K state.

\section{MATERIALS AND METHODS}

Plankton samples for both qualitative and quantitative analysis were collected by sieving 10 litres of water through a plankton net (No. 25, mesh size $64 \mu \mathrm{m}$ ) in the vertical direction. Part of the sample of plankton population thus obtained was examined live while the other aliquot was preserved by fixing in $4 \%$ formalin and Lugol's solution (10gm pure iodine $+20 \mathrm{gm}$ potassium iodide+200cc distilled water to 200cc glacial acetic acid).

Identification of the plankton was done with the help of standard works of Prescott (1939), Nygard (1945), Smith (1950), Edmondson (1959), Cox (1996), and APHA (1998). 


\section{RESULTS AND DISCUSSION}

A total of 67 species of phytoplankton belonging to Chlorophyceae (25 species), Bacillariophyceae (24 species), Cyanophyceae (17 species), Euglenophyceae (1 species) was recorded across seven different springs during the entire study (Table 2).

Among the springs the highest number of algal species was registered at Dubnagin (65), followed by Himalinag (63), Naranag (60), Parinag (50),Malakhnag (40), Kirkadalnag (21) and decreasing to the lowest of 11 species at Batnagin (Table 2). Qualitatively, Chlorophyceae and Bacillariophyceae were the most dominant algal classes in all the springs as against Cyanophyceae. Amongst the reported taxa, the most common species reported from the seven springs were Binucleara tatarana, Hormidium subtile, Cerotonis arcus, Diatomella balfouriana. Gommphonema gracile, Navicula sp. and Microspora amoena being found almost throughout the study period. The greater species diversity of algal flora in springs like Dubnagin and Naranag is likely due to the presence of organic matter (Smith, 1990; Watson et al., 1997) and also due to the application of fertilizers in the agricultural fields causing nutrient enrichment at Dubnagin.

The majority of algal taxa in the present study (e.g. Cocconeis, Synedra, Gomphonema, Fragillaria, Melosira, Cymbella, Cladophora, Oedogonium, Rhizoclonium, Ulothrix, Spirogyra, Closterium, etc.) which has also been reported from springs elsewhere (Whitford, 1956; Bhat and Pandit, 2010) do not display marked seasonal variations as they live under similar ecological conditions. The majority of the diatoms encountered from the springs under study are reported to be cosmopolitan in distribution rendering them unsuitable as ecological indicators (Lowe, 1996). Though, there was no detectable change in dominance or species composition throughout the year in any of the spring communities, yet species richness was found comparatively higher in summer and autumn while as it decreased during the winter and early spring which could be attributed to decreasing water temperature. Though most of the springs hardly exhibited any discernible peak, yet by and large most of the algal groups multiplied profusely in summer-autumn seasons in all the springs (Fig. 2-5). The restricted distribution of certain taxa to given habitats probably reflects the peculiarity of the different habitats or microhabitats (Watson et al., 1997).

Diatoms occupy a wide range of ecological niches (Brook, 1959, 1965; Moss, 1972) which probably accounts for their occurrence in all the studied springs. The greater species diversity of algal flora in springs like Dubnagin, Himalinag and Naranag can be attributed to the different but suitable micro-environments or habitats within these springs and also greater water discharge, area and good water quality, an observation also made by other workers (Cantonatiet et al., 2006; Scarsbrook et al.,2007; Staudacher and Füreder, 2007; Bhat and Pandit, 2010).

The Bray Curtis cluster analysis yielded the results of the study sites into three groups having certain similarity with each other (Fig. 6). Himalinag had less than $50 \%$ similarity with rest of the springs while as Malakhnag, Parinag, Naranag, and Dubnagin had more than $50 \%$ similarity with each other. Similarly Kirkadalnag and Batnagin had nearly $50 \%$ similarity with each other. 
Table 2: Composition of different species of phytoplankton at different sites

\begin{tabular}{|c|c|c|c|c|c|c|c|}
\hline Species & Himalinag & Malakhnag & Kirkadalnag & Parinag & Dubnagin & Naranag & Batnagin \\
\hline \multicolumn{8}{|c|}{ Chlorophyceae } \\
\hline Binuclearia tatarana & + & + & + & + & + & + & + \\
\hline Chara globularis & + & $\ldots$ & + & + & + & + & $\ldots$ \\
\hline Chlormormidium rivularie & + & + & $\ldots$ & $\ldots$ & + & + & 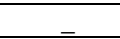 \\
\hline Chlorochytrium lemnae & _- & + & - & + & + & + & - \\
\hline Chlorococum sp. & + & + & $\ldots$ & $\ldots$ & + & + & $\ldots$ \\
\hline Cladophora sp. & + & + & _ & + & + & + & $\ldots$ \\
\hline Closterium sp. & + & + & + & $\ldots$ & + & + & + \\
\hline Cosmarium sp. & + & + & $\ldots$ & - & + & + & $\ldots$ \\
\hline Draparnaldia glomerata & + & _- & - & + & + & + & - \\
\hline Gonalozygon kinahani & + & $\ldots$ & + & $\ldots$ & + & _- & + \\
\hline Hormidium subtile & + & + & + & + & + & + & + \\
\hline Hydrodictyon indicum & + & - & _ & + & + & + & _ \\
\hline Lamnea annulata & + & $\ldots$ & $\ldots$ & + & + & + & $\ldots$ \\
\hline Oedogonium cripsum & + & - & $\ldots$ & $\ldots$ & + & + & - \\
\hline Protococcus virdis & + & + & - & - & + & + & - \\
\hline Rhizoclonium hieroglyphicum & + & + & + & $\ldots$ & + & + & + \\
\hline Sphaeroplea annulina & + & _- & _- & + & + & + & _- \\
\hline Spirogyra sp. & + & + & + & + & + & + & - \\
\hline Spirogyra bullata & + & _- & - & + & + & + & - \\
\hline Straurastrum chactoceras & + & - & + & + & + & $\ldots$ & - \\
\hline Straustraum dilatum & + & + & $\ldots$ & + & + & + & $\ldots$ \\
\hline Ulothrix cylindricum & + & $\ldots$ & - & + & + & - & 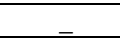 \\
\hline Ulothrix zonata & + & + & - & + & + & + & - \\
\hline Uronema elongatum & + & - & - & + & + & + & - \\
\hline Zygnema stellinum & + & - & - & _- & + & + & _ \\
\hline \multicolumn{8}{|c|}{ Bacillariophyceae } \\
\hline Caloneis amphisbaena & + & + & 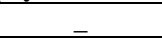 & + & + & + & - \\
\hline Cerotoneis arcus & + & + & + & + & + & + & + \\
\hline Cocconeis placentula var. & + & - & $\ldots$ & + & + & + & $\ldots$ \\
\hline Cylotella opercalata & + & + & _- & $\ldots$ & + & + & _- \\
\hline Cymatopleura elliptica & + & - & - & + & + & + & - \\
\hline Cymbella cistula & + & $\ldots$ & + & + & + & + & $\ldots$ \\
\hline Diatomella balfouriana & + & + & + & + & + & + & + \\
\hline Diatomella tabelleria & + & + & - & + & + & + & - \\
\hline Diploneis eliptica & + & _ & _ & + & + & + & _ \\
\hline Fragillaria sp. & + & + & - & + & + & + & - \\
\hline Gramatophora marrina & + & - & + & + & + & - & - \\
\hline Gymphonema gracile & + & + & + & + & + & + & + \\
\hline Liemophora angliea & + & - & + & + & + & + & - \\
\hline Melosira granulata & + & - & $\ldots$ & $\ldots$ & + & + & - \\
\hline Meridion circulare & + & + & $\ldots$ & + & + & + & $\ldots$ \\
\hline Navicula cincta & + & + & + & + & + & + & - \\
\hline Navicula sp. & + & + & + & + & + & + & + \\
\hline Nitzchia angularis & + & + & + & + & + & + & $\ldots$ \\
\hline Nitzchia microcephala & + & $\ldots$ & $\ldots$ & $\ldots$ & $\ldots$ & + & $\ldots$ \\
\hline Nitzchia travicularis & + & + & + & + & + & + & - \\
\hline Synedra voucheria & + & _- & _- & + & + & + & - \\
\hline Synedra acus & + & + & _ & + & + & + & $\ldots$ \\
\hline Synedra ulna & + & + & _ & + & + & + & + \\
\hline Tabellaria species & + & + & - & + & + & + & $\ldots$ \\
\hline \multicolumn{8}{|c|}{ Cyanophyceae } \\
\hline Anabena affinis & + & + & 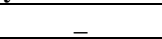 & + & + & + & $\ldots$ \\
\hline Anacystis species & + & - & _ & + & + & + & - \\
\hline Gleotrichia pisum & $\ldots$ & + & $\ldots$ & $\ldots$ & + & + & $\ldots$ \\
\hline Lyngbya sp. & + & + & - & + & + & + & - \\
\hline
\end{tabular}


Cont. Table 2

\begin{tabular}{|c|c|c|c|c|c|c|c|}
\hline Lyngbya subtulis & + & + & _ & + & + & - & _ \\
\hline Merismopodia elegans & + & _ & $\ldots$ & + & + & + & _ \\
\hline Merismopodia tenuissima & $\ldots$ & _ & $\ldots$ & $\ldots$ & + & $\ldots$ & _ \\
\hline Microspora amoena & + & + & + & + & + & + & + \\
\hline Microspora sp. & + & + & + & + & + & + & _ \\
\hline Nodularia laxa & + & _- & _ & $\ldots$ & _- & + & _- \\
\hline Nostoc linckia & + & + & - & + & + & + & _- \\
\hline Nostoc verrucosum & + & + & - & + & + & + & - \\
\hline Oscillatoria limosa & + & + & - & + & + & + & _ \\
\hline Oscillatoria redeki & + & + & _- & + & + & + & _ \\
\hline Oscillatoria linkia & + & + & $\ldots$ & $\ldots$ & + & + & _ \\
\hline Oscillatoria tenuis & + & + & + & + & + & + & _ \\
\hline Phormidiuma utumnale & $\ldots$ & - & $\ldots$ & _ & + & + & _- \\
\hline \multicolumn{8}{|c|}{ Euglenophyceae } \\
\hline Euglena acus & + & $\ldots$ & $\ldots$ & + & + & $\ldots$ & $\ldots$ \\
\hline TOTAL & 63 & 40 & 21 & 50 & 65 & 60 & 11 \\
\hline
\end{tabular}

Present $=+$; Absent $=$ -

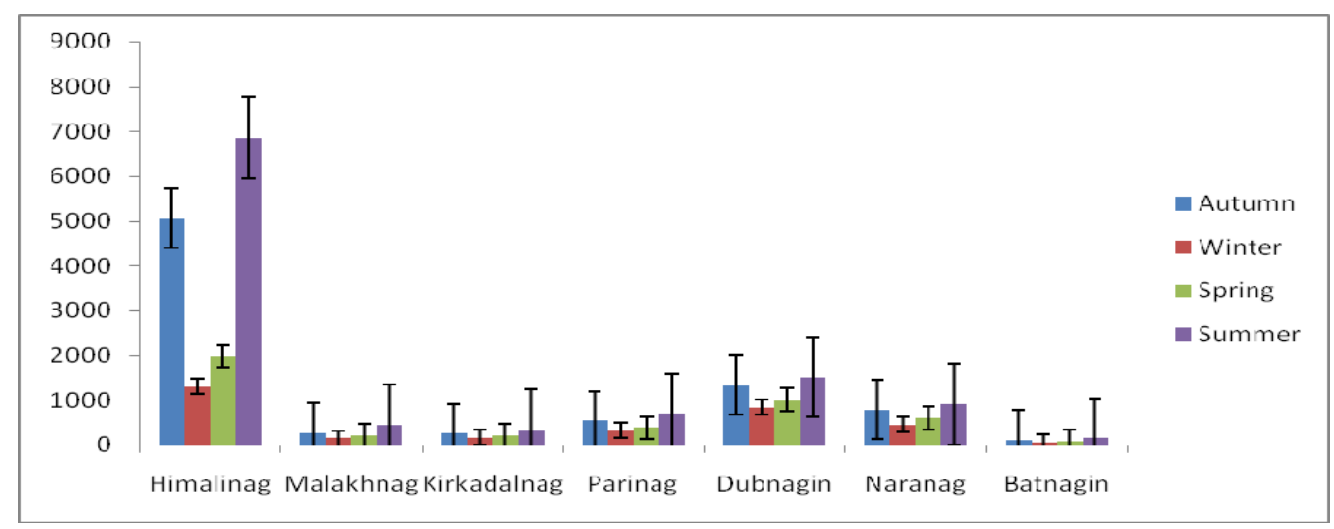

Fig. 2: Seasonal variation in density (No. of ind. $\mathrm{cm}^{-2}$ ) of Chlorophyceae (phytoplankton) during different seasons

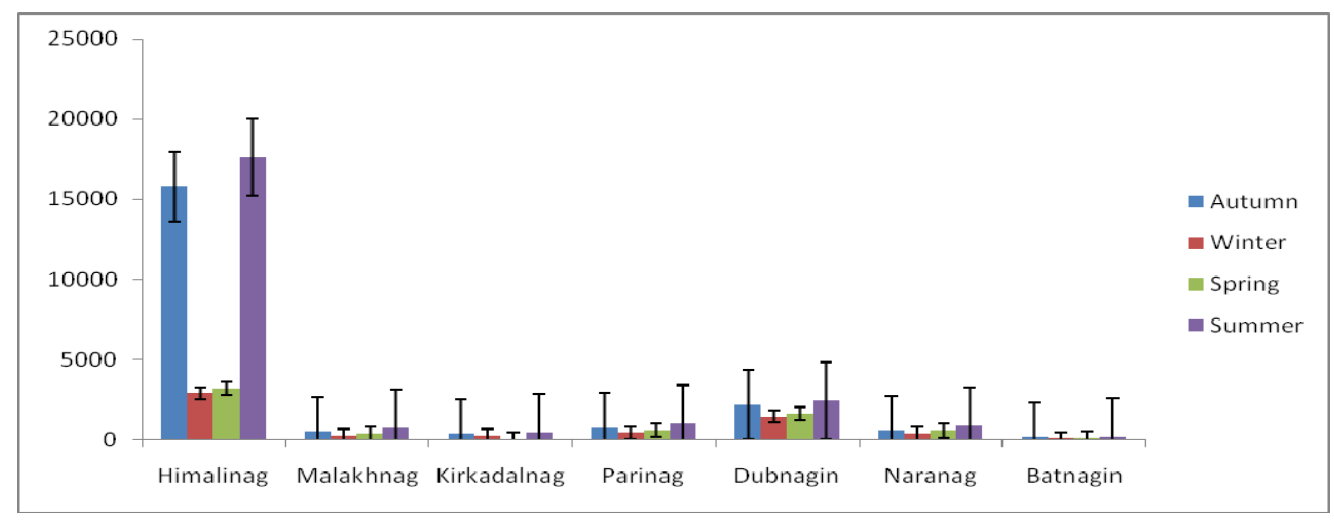

Fig. 3: Seasonal variation in density (No. of ind. $\mathrm{cm}^{-2}$ ) of Bacillariophyceae (phytoplankton) during different seasons 


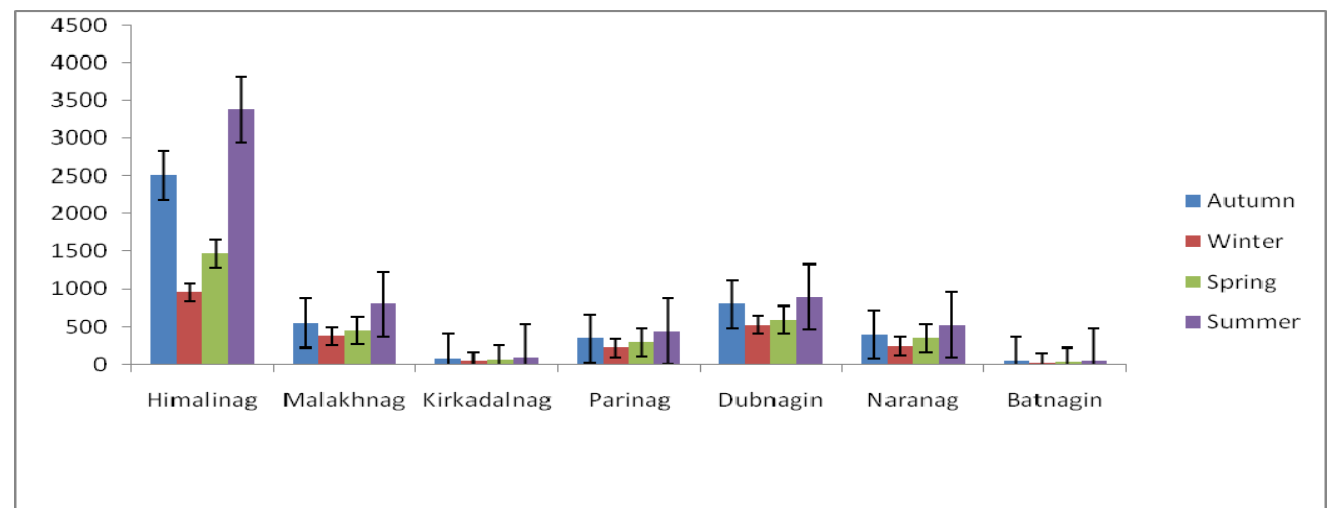

Fig. 4: Seasonal variation in density (No. of ind. $\mathrm{cm}^{-2}$ ) of Cyanophyceae (phytoplankton) during different seasons.

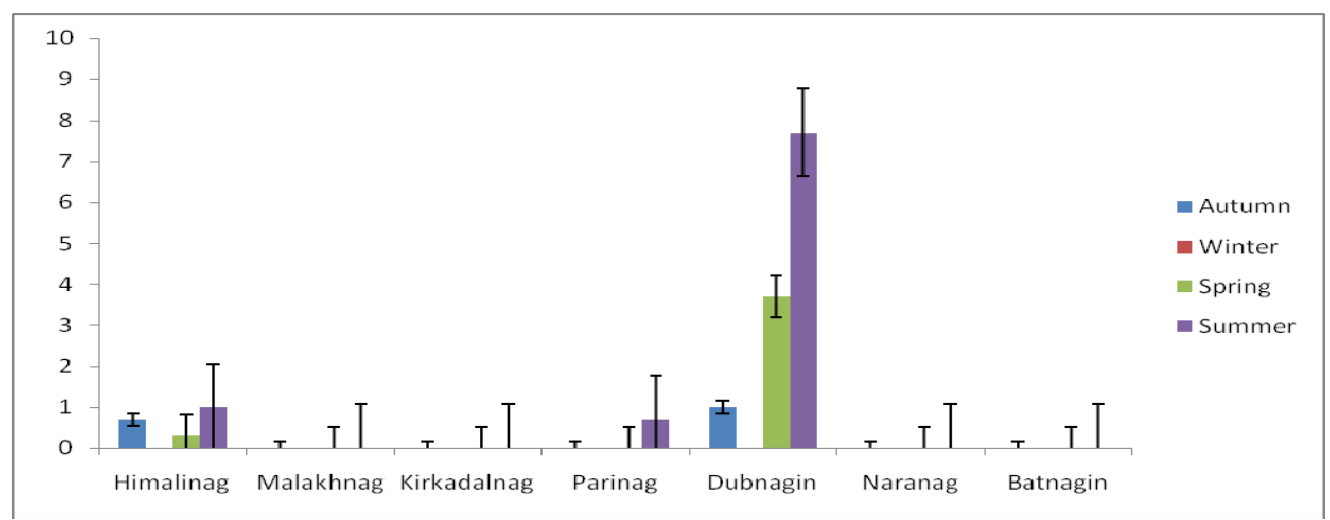

Fig. 5: Seasonal variation in density (No. of ind. $\mathrm{cm}^{-2}$ ) of Euglenophyceae (phytoplankton) during different seasons.

The three diversity indices viz. Shanon, Margalef and Alpha were maximum at Naranag and minimum at Batnagin (Table 3) which might be due to shading effect (Padisak et al., 2006; Kalff, 2002). The low value of indices at Batnagin is because of it being a rheocrene type of spring (water gushes out directly outside) while as other springs are limnocrene (water oozes from bottom). This might be also a reason that the former maintains the lower value of diversity indices. High species diversity values usually reflect diverse and well-balanced communities, while low values indicate stress or impact (Bode et al., 2002). Naranag thus exhibits diverse and well balanced communities than the other springs where low values indicate very little of pollution as evidenced by stress or impact (Bode et al., 2002). The most important stresses in these springs are through organic enrichments, nutrients, pesticides, herbicides and washing clothes.

Table 3: Diversity indices of phytoplankton species at different studied sites

\begin{tabular}{|c|c|c|c|c|c|c|c|}
\hline & Himalinag & Malakhnag & Kirkadalnag & Parinag & Dubnagin & Naranag & Batnagin \\
\hline Taxa_S & 63 & 40 & 20 & 49 & 65 & 60 & 11 \\
\hline Individuals & 15759 & 1288 & 651 & 1489 & 3803 & 1659 & 271 \\
\hline Shannon_H & 3.578 & 3.488 & 2.88 & 3.794 & 3.88 & 4.01 & 2.173 \\
\hline Margalef & 6.415 & 5.446 & 2.933 & 6.57 & 7.764 & 7.958 & 1.785 \\
\hline Fisher_alpha & 8.352 & 7.829 & 3.904 & 9.727 & 11.14 & 12.19 & 2.303 \\
\hline
\end{tabular}




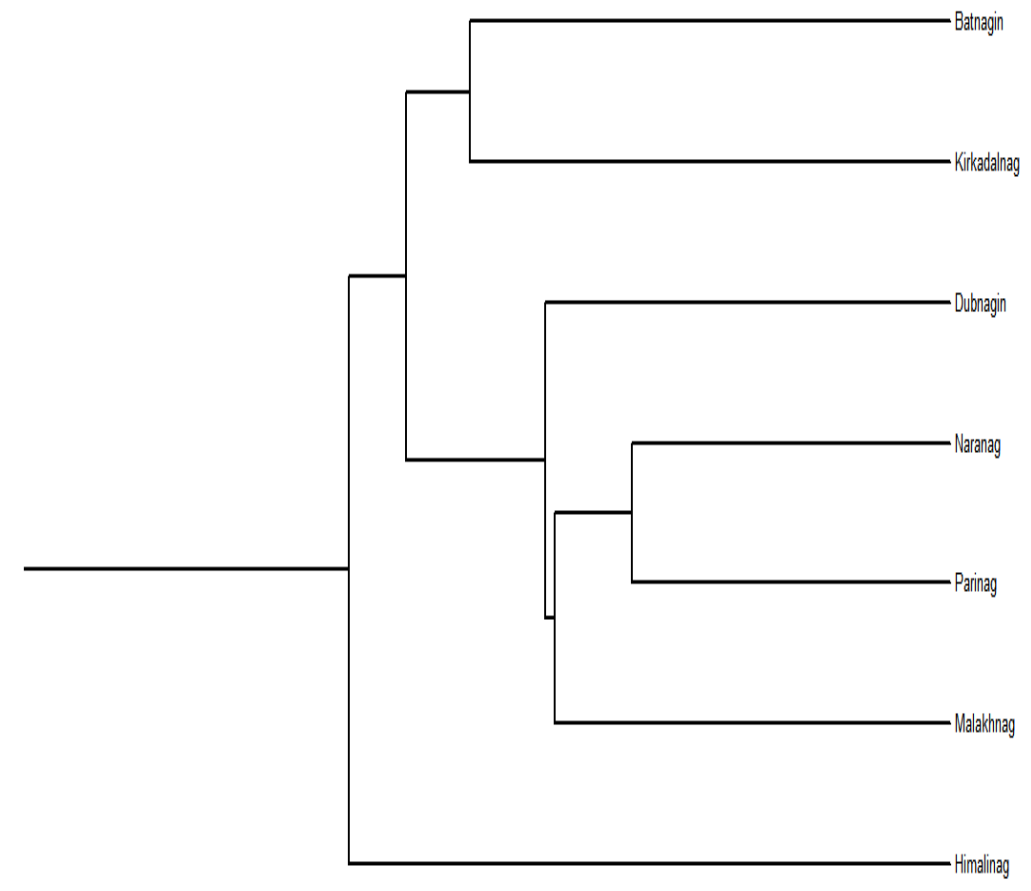

0. \% Similarity

50 .

100

Fig. 6: Dendrogram showing clustering in the respective study sites

\section{ACKNOWLEDGEMENTS}

The study is the part of the work carried out during M.Phil. programme of first author. The authors wish to thank the Head, P.G. Department of Environmental Science, University of Kashmir, Srinagar, India for providing laboratory facilities to carry out this study.

\section{REFERENCES}

A.P.H.A. (1998). Standard Methods for Examination of Water and Waste Water. $20^{\text {th }}$ ed. American Public Health Association, Washington, D.C.

Bhat, S. U. and Pandit, A. K. (2010). Limnochemistry of three freshwater springs of Kashmir Himalaya.J.Hydro-Nepal, 7:54-59.

Bode, R. W., Novete, M. A., Abele, L. E., Heitzman, D. L. and Smith, A. J. (2002). Quality assurance work plan for biological stream monitoring in New York State, Department of environmental Conservation, Albany, New York .

Brook, A. J. (1959). The status of desmids in the plankton and the determination of phytoplankton quotients.J. Ecol., 47: 429-445.

Brook, A. J. (1965). Planktonic algae as indicators of lake types with special reference to the Desmidiaceae.Limnol.Oceanogr., 10:403-411. 
Cantonati, M., Gerecke, R. and Bertuzzi, E. (2006). Springs of the Alps - sensitive ecosystems to Environmental change: From biodiversity assessments to longterm studies. Hydrobiologia, 562: 59-96.

Cox, J. E. (1996). Identification of Freshwater Diatoms from Live Material.Isteds. Chapman and Hall, London, U.K.

Death, R. G., Barquin J. and Scarsbrook, M. R. (2004). Coldwater and geothermal springs, p331-336, In: Harding J.S, Mosley, M.P, Pearson C. and Sorrell, B. (eds.) Freshwaters of New Zealand. New Zealand Hydrological Society Inc. \& New Zealand Limnological Society Inc., Christchurch.

Edmondson, W. T. (1959). Freshwater Biology. John Wiley and Sons Inc., New York. Kallf, J. (2002). Limnology.Prentica Hall, Upper Saddle River, New Jersey.

Knott, B. and Jasinska, E. J. (1998). Mound springs of Australia, p 24-38, In: Botosaneanu, L. (ed.) Studies in Crenobiology. The Biology of Springs and Springbrooks. Backhuys Publishers, Leiden.

Lowe, R. I. (1996). Periphyton patterns in lakes, p. 57-76, In: Stevenson, R.J., Bothwell, M.L. and Lowe, R.L. (eds.), Algal Ecology: Freshwater Benthic Ecosystems. Academic Press, Inc., London.

Moss, B. (1972). Studies on Gull lake, Michigan. I. Seasonal and depth distribution of phytoplankton. Freshwat. Biol., 2: 289-307.

Nygard, G. (1945). Tavlernefra “Dansk Planteplankton” Kobenhavn.

Padisak, J., Grigorszky, I., Borics, G. and Soroczki -Pinter, E. (2006). Use of phytoplankton assemblages for monitoring ecological status of lakes within the framework directives: The assemblage index. Hydrobiologia, 553:1-14.

Pandit, A. K. (1980). Biotic factor and food chain structure in some typical wetlands of Kashmir. Ph.D. Thesis. University of Kashmir, Srinagar, India.

Prescott, G. W. (1939). Some relationship of phytoplankton to limnology and aquatic biology.Pub.Amer. Assoc. Adv. Sci., 10: 65-78.

Rothhaupt, K. O. (2000). Plankton population dynamics: Food web interactions and abiotic constraints. Freshwater Biology, 45:105-109.

Scarsbrook, M., Barquin, J., Gray, D. (2007). New Zealand Coldwater Springs and Their Biodiversity, Department of Conservation, Wellington. Science for Conservation, 278p.

Smith, (1950).The Freshwater Algae of the United States. McGraw Hill Book Co., Inc., New York.

Smith, V. H. (1990). Phytoplankton responses to eutrophication in inland waters, pp.231-249, In: Akatsuka, I.(ed.). Introduction to Applied Phycology.SPB Academic Publishing, Amsterdam The Netherlands.

Soylu, E. N., Maraslioglu, F. and Gonulo, A. l. (2007). Phytoplankton seasonality of a shallow turbid lake. Algological Studies, 123:95-110.

Staudacher, K. and Füreder, L. (2007). Habitat complexity and invertebrates in selected alpine springs (Schütt, Carinthia, Austria) International Review of Hydrobiology, 92 (4-5): 465-479.

Watson, S. B., McCauley, E. and Downing, J. A. (1997). Patterns in phytoplankton taxonomic composition across temperate lakes of differing nutrient status. Limnol. Oceanogr., 42: 487-495.

Whitford, L. A. (1956). The community of algae in the springs and spring streams of Florida. Ecol., 37(3): 433-442. 